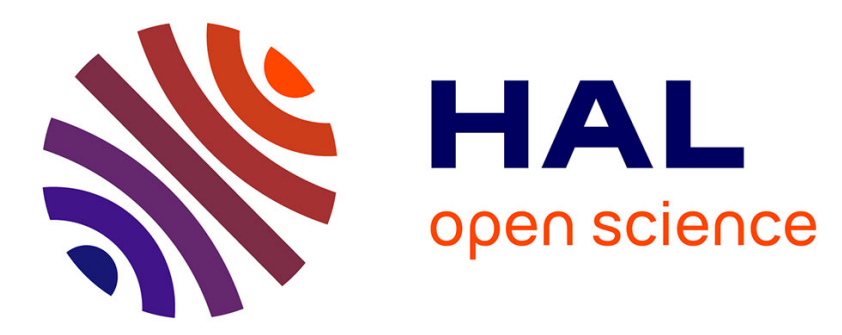

\title{
Learning density in Vanuatu high school with computer simulation: Influence of different levels of guidance
}

\author{
Moli Lemuel, Alice Delserieys-Pedregosa, Maria Antonietta A Impedovo, \\ Jérémy Castéra
}

\section{- To cite this version:}

Moli Lemuel, Alice Delserieys-Pedregosa, Maria Antonietta A Impedovo, Jérémy Castéra. Learning density in Vanuatu high school with computer simulation: Influence of different levels of guidance. Education and Information Technologies, 2016, 10.1007/s10639-016-9527-4 . hal-01417717

\section{HAL Id: hal-01417717 https://hal.science/hal-01417717}

Submitted on 31 Mar 2020

HAL is a multi-disciplinary open access archive for the deposit and dissemination of scientific research documents, whether they are published or not. The documents may come from teaching and research institutions in France or abroad, or from public or private research centers.
L'archive ouverte pluridisciplinaire HAL, est destinée au dépôt et à la diffusion de documents scientifiques de niveau recherche, publiés ou non, émanant des établissements d'enseignement et de recherche français ou étrangers, des laboratoires publics ou privés. 


\section{Learning density in Vanuatu high school with computer simulation:}

\section{Influence of different levels of guidance}

\section{Abstract}

This paper presents a study on discovery learning of scientific concepts with the support of computer simulation. In particular, the paper will focus on the effect of the levels of guidance on students with a low degree of experience in informatics and educational technology. The first stage of this study was to identify the common misconceptions about density, starting from a literature review. Forty eight students $(25 \mathrm{M}$ and $23 \mathrm{~F})$ from two high schools in Vanuatu were then involved in the study. These students were divided into three groups according to the different levels of guidance they received (Unguided; Minimum guidance, Maximum guidance). A pre and post activity questionnaire was designed containing 12 questions. The students underwent a training session with computer simulation about density. Using a descriptive and an inferential statistics method, scores obtained from the three different groups were compared during pre-test and post-test analyses. From the analyses it was found that the construction of knowledge from discovery learning activities occurs with or without guidance, however the amount of guidance received has an influence on the depth of conceptual understanding.

Keywords: density; high school; computer simulations; guidance.

\section{Introduction}

In order to keep up with the rapidly changing economic and social situation, learning of high quality is required (Miyake, 2007). At the same time, with the advent of technologies supporting online learning platforms such as Massive Open Online Course (MOOC), students have to be autonomous in their learning and show the ability to be self-organized in order to personalize their study.

Discovery learning is a technique in which learners gain knowledge about a concept by generating hypotheses and then designing and executing experiments to validate these 
hypotheses. (Lazonder, Wilhelm, \& Hagemans, 2008; Pellas, 2014). In science education this approach is widely used, stressing the centrality of authentic learning (Smitha, 2012).

More recently, discovery learning has received increased attention due to the benefits of computer simulations in increasing the effectiveness of learning in an assisted or guided environment (Wieman, Adams, Loeblein, \& Perkins, 2010). Of current interest, however, is a discussion about the right level of guidance during discovery learning of scientific concepts with the support of computer simulation (Alfieri, Brooks, Aldrich, \& Tenenbaum, 2011; De Jong \& Joolingen, 1998; Honomichl \& Chen, 2012; Kirschner, Sweller, \& Clark, 2006; Mayer, 2004; Leutner, 1993).

Learning science in classrooms where there is limited constraints on students' actions, minimal feedback and minimal instructor intervention or guidance, can result in learners becoming confused with possible negative effects upon learning (Alfieri et Crooks, Aldrich, \& Tenenbaum, 2011; Hardiman, Pollatsek, \& Well, 1986). Learners therefore may find it difficult to achieve the expected objectives due to lack of support in the form of instruction (De Jong \& Joolingen, 1998). On the other hand too much guidance can create within learners a sense of dependency. Indeed, Leutner (1993) advises that while higher levels of support helps to increase the learner's domain knowledge, it may hinder the acquisition of functional knowledge. A sustained level of high support over a period of time may result in the formulation of content knowledge rather than content understanding. Content knowledge can be retrieved from the long-term memory but unlike content understanding cannot be applied in different situations.

This paper will present an investigation of students' use of discovery learning techniques to study the concept of density using computer simulation. In particular, there will be a focus on the effect of three levels of guidance (no guidance, minimum and maximum guidance) on 
students from a Least Developed Country (LDC) who have a low degree of experience in informatics and educational technology

The first section of this paper will present a discussion about how an understanding of the concept of density is developed and how new technology and computer simulations support this conceptual development. The second section of the paper will present an outline of this research which was conducted in a developing country and the findings from this research.

\section{The intuitive understanding of the concept of density and the common misconceptions}

Density is a science topic introduced in elementary and primary grade levels as floating and sinking (for example, wood floats on water because it has a lower density than water; while a metal anchor sinks because it has a higher density than water). It is, however, a complex scientific topic and a difficult concept for students to understand because it is abstract in nature and is derived from the concepts of mass and volume (Hitt, 2005; Radovanovic \& Slisko, 2012). The difficulties in understanding the concept of density become amplified when mathematical formulas are attached to it during middle school and beyond (Dawkins, Dickerson, McKinney, \& Butler, 2008). Studies have been carried out by Smith, Snir \& Grosslight (1992) on children's conceptual change showing their earliest concept of density is all about heaviness and size. The greater the size of an object, the heavier it is.

Kohn (1993) suggests that children between 3 and 5 years demonstrate a very basic concept of density when they have to predict if an object floats or sinks. Kohn's study demonstrates this age group's reliance on certain properties of the object (mass, volume, density and material) to predict the waterline of the objects. The results indicate the predictive ability of children, but also the specific physical properties upon which these predictions seem to rely, showing an intuitive understanding of density. Kohn's study shows that children demonstrate

certain basic concepts and skills earlier than that attributed by Piaget to a later period of 
development. Between the age of 5 and 7 the concept of density as heaviness for size seems to contribute to the concept of weight such that there is no differentiation between weight and density but rather that both are included in the concept of heaviness.

Piaget (2013) proposed that the concepts of weight and density develop as a result of children taking into account the viewpoints of others rather than their own. Initially children may judge that an object is lighter, but sometime later may say that it is lighter for them but heavier for the water because it sinks in it. At the age of 9 and 10 they relate the density of one object with that of another and may conclude that a material floats because it is lighter than water. Furthermore, at the age of 14 to 22 according to Hewson (1986) students relate the density of a material to the denseness in the packing of its particles. This explanation may be inadequate or incomplete due to the student's conceptions of mass and volume being dependent upon their conceptions of the arrangement, the concentration and the mass of the particles.

\section{Common misconceptions on density}

Randovanovic and Slisko (2012) stated that research has shown students have certain experiences which assist them to formulate their own theories about sinking or floating. Many of these theories however are either misconceptions which means that the theories do not agree with the current scientific view (Helm, 1980) or are only true up to a certain point but lacking the proper scientific explanation. In investigating 108 grade eight students' conceptions of sinking and floating Costu and Unal (2005) reveal eight common problematic areas where students have difficulties and misconceptions. These include misconceptions about

- the effect of the mass of an object on floatation: e.g. the object with more weight instead of mass sinks compared to those with less weight 
- the determination of the density of an object: e.g. density is the weight of an object

- the effect of the density of an object on floatation: e.g. the density of an object hanging in liquid is equal to that of a floating object

- the effect of the density of the liquid on floatation: e.g. a sticky liquid makes things float

- the effect of the volume of the liquid on floatation: e.g. a large amount of water makes things float

- the calculation of the buoyancy applied by the liquid on an object: e.g. floatation is the result of liquid pushing on the object

- the effect if a floating object has a hole: e.g. things with holes sink

- the effect of the size of an object on its floatation: e.g. when a floating object is cut into two parts, the bigger piece will sink or the volume of the sinking part will increase.

These misconceptions have commonalities and are often resistant to change through traditional methods of teaching (Champagne, Klopfer, \& Gunstone, 1982; Hewson 1984). To conquer these misconceptions more effectively, it is necessary to provide students with engaging and motivating opportunities that challenge their presently held conceptions. Involving students in discovery learning could play an important role in helping students to give up their misconceptions and adopt a scientifically accepted understanding of the concept, especially if supported by technology.

\section{Learning physics using computer simulations}

Computer simulation in general refers to any electronic software that was designed for interaction and manipulations of parameters in a particular field or topic to discover certain relationships. It allows learners to interact with materials, manipulate variables, explore phenomena, and affords them opportunities to notice patterns, discovering underlying causalities (Alessi \& Trollip, 1991; Alfieri et al. 2011; Jong, 1991; Wieman \& Perkins, 2006). 
Using computer simulations in science teaching has certain advantages in that it serves the purpose of learning science concepts effectively (Jong \& Joolingen, 1998; Ren \& Xie, 2004; Wieman, Adams, \& Perkins, 2008; Wieman et al., 2010; Xie \& Tinker, 2006). An interest in computer simulation in the teaching of science in recent years has increased due to the higher availability of technology in classrooms and the possibility of using new pedagogical strategies (Jong \& Joolingen, 1998; Wieman et al., 2008), with a centrality on developing observation and interaction skills (Wieman \& Perkins, 2006). The use of computer simulations in science teaching motivates students (Wieman \& Perkins, 2006; Wieman et al., 2010; Xie \& Tinker, 2006), showing that students generally enjoy this form of education (Damassa \& Sitko, 2010). Also, the use of computer simulations in science teaching encourages exploration of situations that are not always possible to observe in common school laboratories or in real life situations such as interacting with molecules, atoms, and electrons (Xie \& Tinker, 2006).

Computer simulations in physics teaching generally show a visual model of the behavior of a physical system and allow students to explore and to visualize graphic representations (Concari, Giorgi, Cámara, \& Giacosa, 2006). As a result of exploring with simulations, students get to understand the abstract and counterintuitive concepts, like quantum mechanics (Mckagan et al. 2008). Steinberg's research (2000) showed clearly that the students who were taught using simulations had a better understanding of the topics taught. Similar results have been obtained by other researchers (Chang, Chen, Lin, \& Sung, 2008; Leutner, 1993; Psycharis, 2011; Steinberg, 2000; Wieman, Adams, Loeblein, \& Perkins, 2010).

There are many types of online computer simulations for learning physical phenomena. In this paper, the focus will be on PhET simulation for density concept (Santos \& Dos, 2012). 


\section{PhET simulations to learn density}

PhET is a free simulations software that can be downloaded to be used offline using Java and flash based players (http://phet.colorado.edu/). PhET simulation deals with density, mass and volume. It is a combination of three associated topics under the umbrella of density. It is based on common misconceptions about learning density. Guidance and feedback responses were built into the simulations to scaffold student's learning (Wieman et al., 2008). Even though it is strongly founded on physical laws, it is also user friendly and contains resources for both teaching and learning (Perkins et al., 2006). There is an increasing use of this software in schools (Zhang, 2014).

The density PhET simulation is composed of a simple interface which contains three main elements: blocks, block settings and water (Figure 1).

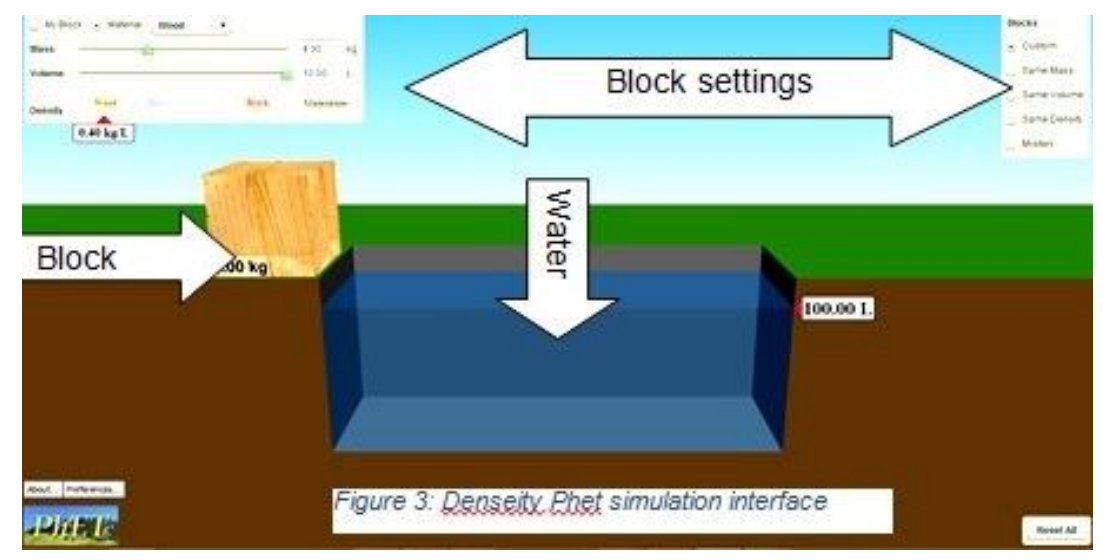

Figure 1: Screenshot of PhET interface

The idea is simply to drop blocks made of different materials (wood, ice, cement, aluminium etc.) into the water to see whether they float or sink. In doing so the block displaces a volume of water which corresponds to the percentage of the block submerged. The numerical figure for mass and volume of these blocks is indicated so students are expected to see the relationship between mass and volume which is density. These two properties of density 
directly influence the floatation of an object. The sliding scales in the computer simulation allow students to manipulate either the mass or volume of the block and see how this influences the other corresponding quantities and the overall effect of this on floatation.

In the following section the study of the use of the PhET software to develop an understanding of the concept of density in the high school context will be presented.

\section{Study}

\section{Research questions}

The study considers two research questions:

- How do different levels of guidance (unguided, maximum, minimum) in using computer simulation software impact on students' success in understanding the concept of density?

- Which discovery approach is most effective in assisting students to give up their misconceptions and adopt a more scientifically accepted understanding of density?

\section{Context and participants}

The research is set in Vanuatu, a Least Developed Country (LDC), situated in the South Pacific Ocean and made up of 83 islands. The new National Curriculum is encouraging schools to use information communication technology (ICT) as a resource to aid learning in the classrooms (ITU, 2013). In regard to the research design, the literature review demonstrated how the initial understanding of density concepts by the students is derived mainly by interacting with their surroundings. Indeed, according to the Vanuatu science syllabus (Ministry of Education Republic of Vanuatu, 2013a, 2013b), density is not a core topic and therefore is not taught in class, although elements are integrated into other science topics such as pressure. 
Forty eight students, (25 $\mathrm{M}$ and $23 \mathrm{~F}$ ) having an average age of 17-18 years from two high schools in Vanuatu were selected to participate in the study. Five year 12 classes were used (3 in one school and 2 in the other). The students had a low degree of computer literacy, evaluated through a self-declarative test. Indeed, $80 \%$ of the candidates indicated that they did not have access to a personal computer. The schools have one computer laboratory but each class is given only an hour of computer lessons per week. In addition, students know about simulation but most of them had not had the opportunity to access this software. Five students in the study indicated that they had used a computer simulation before.

An hour workshop or training was conducted with all maths and science teachers in these two schools before the experiment. This was deemed necessary as most of the teachers indicated that they had never used computer simulations in their teaching even though some had experiences in using them for their own learning. Only two senior science teachers indicated that they had used computer simulation for demonstration purposes. The role of the teachers was to help organise the pre- and post-testing and to provide supervision during the experiments and the three different phases of the research.

The experiment was carried out once for all three groups using each school's computer facilities but at different times in the two schools. All three groups used the one room, however the students in each group were allocated to use computers in certain parts of the room with no communication allowed between the different groups. The 48 students were randomly selected into three groups of 16 students with each group receiving a different level of guidance.

\section{Test measuring: a questionnaire about density}

Firstly the common misconceptions about density were identified based on the literature review (Çepni \& Şahin, 2010, 2012; Costu \& Unal, 2005). The eight misconceptions of Costu 
and Unal (2005) were analysed against the density PhET simulation conceptual areas where 6 misconceptions were identified to have been addressed by the density simulation. The twelve questions in the questionnaire were designed to identify and highlight the misconceptions in the 6 conceptual areas outlined in Table 1 below, and provide opportunities for the research participants to challenge and adjust their thinking.

\begin{tabular}{|c|c|c|}
\hline & Density Relationships & Misconception \\
\hline $\mathrm{I}$ & $\begin{array}{l}\text { Relationship between floating and } \\
\text { sinking (light object floats and heavy } \\
\text { objects sinks) }\end{array}$ & $\begin{array}{l}\text { The weight of an object determines if it will } \\
\text { sink or float. Heavy objects always sink, and } \\
\text { light objects always float. }\end{array}$ \\
\hline II & $\begin{array}{l}\text { Relationship between an object's mass } \\
\text { and volume (the bigger the size the } \\
\text { heavier it is) }\end{array}$ & $\begin{array}{l}\text { Bigger objects are heavy and therefore sink } \\
\text { when placed in water }\end{array}$ \\
\hline III & $\begin{array}{l}\text { Relationship between an object's } \\
\text { change in volume upon its density } \\
\text { (change in an object's volume or size } \\
\text { also changes its density) }\end{array}$ & $\begin{array}{l}\text { The smaller something is, the less density it } \\
\text { has. So smaller objects are less dense than } \\
\text { larger objects } \\
\text { If you cut a piece of wood in half, the } \\
\text { density of each piece is now half of the } \\
\text { original piece } \\
\text { If you take a ball of clay and add more clay } \\
\text { to it, the ball will get larger and the density } \\
\text { will increase }\end{array}$ \\
\hline IV & $\begin{array}{l}\text { Relationship between an object's } \\
\text { change in Mass upon its density } \\
\text { (change in an object's mass also } \\
\text { changes its density) }\end{array}$ & $\begin{array}{l}\text { The less mass an object has, the less its } \\
\text { density }\end{array}$ \\
\hline $\mathrm{V}$ & $\begin{array}{l}\text { Relationship between densities of two } \\
\text { different objects. (Two different } \\
\text { objects with the same mass have the } \\
\text { same density) }\end{array}$ & $\begin{array}{l}\text { A rock and a piece of iron having the same } \\
\text { mass }(100 \mathrm{~g}) \text { also have the same density } \\
\text { Wood and plastic objects float. Metal objects } \\
\text { sink }\end{array}$ \\
\hline VI & $\begin{array}{l}\text { Relationship between an object's mass } \\
\text { and volume to the amount of water it } \\
\text { displaces (the amount of water } \\
\text { displaced is equal to the volume of the } \\
\text { object that is submerged) }\end{array}$ & $\begin{array}{l}\text { The size of an object is responsible for the } \\
\text { displacement of water. }\end{array}$ \\
\hline
\end{tabular}

Table 1: Relationships and misconceptions about density

Misconceptions in density happen at two levels, the micro and macro and it is argued that learners require both levels to fully understand the concept of density. Due to the focus the 
designers of density $\mathrm{PhET}$ computer simulation have on the macro aspect of density, however, this research will only focus on density concepts at the macro level. Taking into consideration the identified misconceptions about density and the macro focus of PhET on density, 12 questions were designed for the questionnaire. Table 2 outlines content about density that students have to learn, the context of the application of the concept and the number of the corresponding question from the questionnaire.

\begin{tabular}{|c|c|c|c|}
\hline \multicolumn{2}{|c|}{ Content about density } & \multirow{2}{*}{$\begin{array}{l}\text { Application of concept } \\
\begin{array}{l}\text { Defining floating and sinking and giving reasons } \\
\text { why objects float or sink }\end{array}\end{array}$} & \multirow{2}{*}{$\begin{array}{l}\text { Correspond } \\
\text { ing } \\
1\end{array}$} \\
\hline $\mathrm{I}$ & $\begin{array}{l}\text { General knowledge about } \\
\text { the phenomena (Density) }\end{array}$ & & \\
\hline \multirow[t]{3}{*}{ II } & \multirow{3}{*}{$\begin{array}{l}\text { Density of a material is } \\
\text { specific to that material } \\
\text { (No two materials have } \\
\text { similar density). } \\
\text { Floatation of an object } \\
\text { depends on the material } \\
\text { that it is made up of and } \\
\text { not its weight. }\end{array}$} & Different material and mass with similar volume & 2,5 \\
\hline & & $\begin{array}{l}\text { Different material, different volume with similar } \\
\text { mass }\end{array}$ & 7 \\
\hline & & Same material, same volume but different shape & 11 \\
\hline \multirow{3}{*}{$\begin{array}{l}\text { II } \\
\text { I }\end{array}$} & \multirow{3}{*}{$\begin{array}{l}\text { Objects float if they are } \\
\text { light for their size and } \\
\text { sink if they are heavy for } \\
\text { their size. }\end{array}$} & Two of the same materials having similar mass & \\
\hline & & but different volume & $4,6,8$ \\
\hline & & $\begin{array}{l}\text { Two of the same materials with similar volume } \\
\text { but different mass }\end{array}$ & 3 \\
\hline I & $\begin{array}{l}\text { The amount of water } \\
\text { displaced by an object is } \\
\text { equal to the volume of } \\
\text { that object submerged }\end{array}$ & $\begin{array}{l}\text { Displacement of water from different objects with } \\
\text { the same volume at different submerged levels in } \\
\text { the water }\end{array}$ & 12 \\
\hline $\mathrm{V}$ & $\begin{array}{l}\text { Objects float depending } \\
\text { on their density } \\
\text { compared to water; for } \\
\text { an object to float its } \\
\text { density needs to be less } \\
\text { than that of water }\end{array}$ & $\begin{array}{l}\text { Two different materials with similar volume but } \\
\text { different masses submerged in two different fluids } \\
\text { (water \& oil) Fluids with different density }\end{array}$ & 9,10 \\
\hline
\end{tabular}

Table 2: Content about density and corresponding question

The first question in this research questionnaire was taken from a tested research questionnaire from Çepni, Şahin, \& Ipek (2010) and the following 11 questions from a 
research questionnaire developed by Derradj (2014) Each question required a two tier response, a selection of the correct multiple choice answer and then a selection of the reason for that answer. (See Appendix A for sample questions from the questionnaire) The second tier response of the multiple choice reasons for the answer given, have been developed by the researchers involved in this research. The second tier choices were created to explain the possible reasons for the first tier selection. The score system used was adapted from (Şahin, 2010) with some amendments for the second tier reasoning response.

- For the first multiple choice section the score is: correct choice (CC) 2 points; incorrect choice (IC) 1 point; no response or empty (E) 0 point.

- For the multiple choices section with reasons the score is: correct reasoning (CR) 5 points; partial correct reason (PCR) 4 points; reason including alternative concepts (RIAC) 3 points; incorrect reason (IR) 2 points; unrelated reason (UR) 0 point.

An individual with a total point score of 7 for an item shows a correct reasoning for a particular choice or concept. The scores obtained from the 12 questions during pre-test and post-test were totalled out of 84 points.

\section{Research design and data collection}

The research was preceded by a period of familiarization with the software. The students had two hours to explore PhET simulation computer under the teacher's supervision. During this familiarisation phase, students having difficulties with this software were identified and assisted, giving them extra computer practice time if necessary to gain more confidence in the use of the software. In this way, all students had a sufficient level of knowledge to use the software during the research. 
The research design was organized into three main phases:

I) Pre-test phase: consisted of the filling in of the 12 two-tier questionnaire in an hour. Each student completed the questionnaire individually and anonymously. The tests were given a numerical code so that individual student's pre- and post- testing could be analysed.

II) Training session phase: consisted in the using of the PhET simulation computer software. Students were given 30 minutes to learn how to navigate around the software.

The training session consisted of one hour of using PhET simulation on the topic of density. In this session, a designed activity was used (http://phet.colorado.edu/sims/density-andbuoyancy/density_en.html, ) (See Appendix 1 for an example of the activity tasks). To perform this phase, the students were seated according to their randomly selected groups with each group of 16 receiving their designated level of guidance. The three levels of guidance were differentiated by the different levels of instructions provided, as outlined below.

1. Unguided group: the students receive only the simulation operational instructions below

\begin{tabular}{|l|l|}
\hline 1 & Identify PhET simulation logo on the desktop and double click to run \\
\hline 2 & On the PhET interactive simulation interface, click on play with sims \\
\hline 3 & On the PhET simulation category on the left side of the page, click physics \\
\hline 4 & $\begin{array}{l}\text { All physics PhET simulation will be displayed but only select density by clicking on } \\
\text { its icon }\end{array}$ \\
\hline 5 & A density PhET simulation interface will be displayed \\
\hline 6 & $\begin{array}{l}\text { On the top right and top left of the interface are block settings which you can adjust } \\
\text { or manipulate to give an outcome on the block's material, mass and volume } \\
\text { depending on which setting you have selected. }\end{array}$ \\
\hline 7 & \begin{tabular}{l} 
To move the block, click and hold on the block then drag. \\
\hline
\end{tabular} \\
\hline
\end{tabular}

2. Minimum Guided Group: the students receive simulation operational instruction as for the Unguided Group plus concept probing questions, outlined below, provided by the teachers on paper to give some form of directions. 


\begin{tabular}{|l|l|}
\hline 1 & What is density? \\
\hline 2 & $\begin{array}{l}\text { What is the relationship between an object's density and the change in its } \\
\text { volume? }\end{array}$ \\
\hline 3 & $\begin{array}{l}\text { What is the relationship between the density of one object with the density of } \\
\text { another object having the same volume? }\end{array}$ \\
\hline 4 & What is the relationship between an object's density and the change in its mass? \\
\hline 5 & What is the relationship between an object's mass and volume? \\
\hline 6 & $\begin{array}{l}\text { What is the relationship between an object's mass and the amount of water it } \\
\text { displaces? }\end{array}$ \\
\hline 7 & $\begin{array}{l}\text { What is the density of an object that hangs (floats under the water surface) in } \\
\text { water? }\end{array}$ \\
\hline
\end{tabular}

3. Maximum Guided Group: the students receive simulation operational instruction; the concept probing questions and detailed written procedures of the task activity (Appendix B). In addition, the concept probing, questions were asked during the experiment session in a personalized way.

In their respective groups, students worked collaboratively in pairs to acquire a conceptual understanding of density using the computer simulation. A summary of the guidance for each group is shown in Table 3:

\begin{tabular}{|c|l|c|c|c|c|c|}
\hline \multicolumn{2}{|c|}{$\begin{array}{c}\text { Type of discovery } \\
\text { guidance }\end{array}$} & $\begin{array}{c}\text { Simulation } \\
\text { operational } \\
\text { instructions }\end{array}$ & $\begin{array}{c}\text { Concept } \\
\text { probing } \\
\text { questions }\end{array}$ & Procedures & $\begin{array}{c}\text { Number of } \\
\text { students }\end{array}$ & $\begin{array}{c}\text { Number of } \\
\text { pairs }\end{array}$ \\
\hline I & Unguided & $\mathrm{x}$ & - & - & 16 & 8 \\
\hline II & Min guided & $\mathrm{x}$ & $\mathrm{x}$ & - & 16 & 8 \\
\hline III & Max guided & $\mathrm{x}$ & $\mathrm{x}$ & $\mathrm{x}$ & 16 & 8 \\
\hline
\end{tabular}

Table 3: Types of guidance in computer simulation

The training session was video recorded by the researchers to observe the discussions that took place between the pairs as they worked through the simulation activities. 
III) Post-test phase: the same questionnaire from the pre-test was once again filled in individually and anonymously by the students.

\section{Data analyses}

First, a descriptive data analysis was used on the overall scores from the pre-test and post-test questionnaire responses. Then, an inferential statistics method was used, to test the hypothesis and to draw conclusions about the sample. Since the measuring scale was ordinal, a non-parametric data treatment known as Mann-Whitney U test was used to test whether one group performed better than another without making the assumption that the values showed a normal distribution. It was expected that there would be a difference between the control group (Unguided Group) at post-test in comparison with the two other groups when analyzing the improvement in scores between pre-test and post-test. So, there was a comparison of scores obtained from the three different groups during pre-test and post-test analyses in order to find evidence of conceptual changes that may have occurred after the experience.

Finally, there was an analysis of the videos taken during the training sessions and the resultant ethnographic notes of the critical conversations between the student pairs, provided evidence of the conceptual difficulties that were discussed by the pairs of students.

\section{Results}

The result section is divided into two sub-sections: the descriptive statistics and the inferential statistics.

\section{Descriptive statistics}

This descriptive analysis section involves analysis of mode, median and range of the test score results from the pre-test and post test data. The shift (in numerical numbers) refers to 
the results obtained from the comparison of mode between pre- and post-test (mode at posttest subtract mode at pre-test for each group). A positive shift means, the mode has increased in post-test compared to pre-test. The shift in the median can be interpreted as the shift from intuitive concept towards a more scientific concept of density. A range is the simplest measure of dispersion; it is the difference between the highest and the lowest scores obtained in an assessed environment. In this research, the range is an indicator of how much scientific concepts students know or the scientific scope on the topic of density.

In an analysis of the mode data, the Unguided Group's score mode had shifted 2.5 units, the Minimum Guided Group had a shift of 3.5 units while the Maximum Guided Group had a shift of 4.5 units. The comparison of the range of the pre-test against the post-test for each grouping showed a 2 units loss for the Unguided Group, while the Minimum Guided Group showed a gain of 2 units while the Maximum Guided Group a gain of 8 units. The progress of each grouping has been summarized in Table 4. It shows a comparison between individual participants' scores in the pre-test and the post-test. The table of progress has three indicators, the positive $(+)$ representing progression; the zero $(0)$ representing no progression, and the negative (-) representing regression.

After the training session, results from the Unguided Group showed that 12 pairs had achieved progression, one pair with no progression and 3 pairs with regressions. The Minimum Guided Group had 10 pairs with individual progression, 6 pairs with regressions and none with no progression. The Maximum Guided Group had 11 pairs with progression, 5 pairs with regression and none with a no progression result.

\begin{tabular}{|l|l|c|c|c|c|}
\hline \multicolumn{2}{|l|}{ Group } & $(-)$ & $(0)$ & $(+)$ & Tot \\
\hline I & Unguided & 3 & 1 & 12 & 16 \\
\hline II & Min guided & 6 & 0 & 10 & 16 \\
\hline III & Max guided & 5 & 0 & 11 & 16 \\
\hline & Total & 14 & 1 & 33 & 48 \\
\hline
\end{tabular}


Table 4: Students' scores after the intervention of computer simulation

A further analysis of individual scores for each question was also completed because of the similarity of scores obtained across the groups. Scores for individual questions were then tallied to give the whole group performance. The differences were represented by a number with a sign which symbolised a gain in score, a positive $(+)$ sign for progression, a zero (0) for a no gain and a negative sign (-) in front of a number for a regression. The three tables showing question score differences for each grouping were then summarised into a summary table of correct reasoning (Table 5). The positive sign (+) represents a gain in correct reasoning for a particular concept tested by the question, with a shift from an intuitive/preconception on density into a more scientific conception; zero (0) represent sustaining of preconception, and a negative sign is a representation of a loss in correct reasoning.

\begin{tabular}{|c|c|c|c|c|c|c|c|c|c|c|c|c|c|}
\hline \multicolumn{2}{|c|}{ Groups } & Q1 & Q2 & Q3 & Q4 & Q5 & Q6 & Q7 & Q8 & Q9 & Q10 & Q11 & Q12 \\
\hline $\mathrm{I}$ & No guide & 0 & + & + & + & - & + & + & - & + & - & - & 0 \\
\hline II & Min guide & + & - & 0 & - & - & - & 0 & - & 0 & - & 0 & - \\
\hline III & Max guide & + & + & 0 & + & + & + & + & - & + & 0 & + & 0 \\
\hline
\end{tabular}

Table 5: Comparison of correct reasoning obtained in each groups

The Maximum Guided Group secured a gain in correct reasoning (CR) for 8 questions and 3 no gains. The Unguided Group secured a gain in correct reasoning for 6 questions, 2 no gains and 4 questions where there was a loss of correct reasoning. The Minimum Guided Group secured a gain in correct reasoning for only 1 question, seven questions where reasoning was lost and four no gains. 
Question eight was the only question where all three groups failed to gain in correct reasoning and indeed each group showed a loss in reasoning. Taking into account the fact that questions 4,6 , and 8 were all testing for the same effect by using the same material with similar mass but different volumes and question 4 and 6 present a similar characteristic with only the Minimum Guided Group with a fail in both, it can be concluded that maybe question 8 was not clear enough.

\section{Inferential statistics}

The results indicated that there are no two groups differing significantly on their scores of pre-test and post-test except for the overall scores of post-test compared to pre-test. It can be noted however, that the U-value of comparison of scores pre-test vs post-test is 857.5 and the p-value is significant $0.03156(\mathrm{p}<0.5)$.

\section{Discussion}

In this section a discussion about the three level of guidance for each group is presented, taking into consideration the results from descriptive and inferential statistics. For a critical analysis, in this section the video and the ethnographic notes taken during the training sessions are also taken into account.

Students in the Unguided Group due to the lack of guidance, were required to self-organize the information and take control of their own learning. Even though the candidates were in senior high schools, they were not familiar with pure discovery learning methods and therefore should be regarded as novice discovery learners, characteristically experiencing confusion and discouragement whenever faced with difficulty (Alfieri et al., 2011). From the video and the ethnographic notes, it was observed that students in this group spent the first quarter of the hour in a high engagement of paired discussions but failed the first step towards learning which is to set their goals. 
In the Minimum Guided Group, the questions on paper might have acted as a guide however students demonstrated a need for more probing questions. The central tendency and dispersion results indicated that the Minimum Guided Group had a positive shift towards scientific concepts. Students in this group, however, were weak in answering probing questions and found difficulties in giving explanations for their answers. This result could be related to the difficulty of the topic. Indeed, scientific concepts like density require processing to reorganize and restructure the concept in order to achieve scientific knowledge (Ünal \& Coştu, 2005). From the video and the ethnographic notes, it was observed that individuals in this group spent more time discussing and interacting with the computer simulation in trying to find answers to the questions instead of internalizing the scientific concepts the answers to the question were trying to promote.

The Maximum Guided Group seemed to reduce the cognitive complexity of the task in order to maximize learning.and maximize learning. Even though the Maximum Guided Group had a high number of students who regressed in the overall raw score performance, the central tendency, the dispersion, and the correct reasoning score analysis demonstrated overall that it had performed better than the two other intervention groups. A more vivid indication of conceptual change was shown in the analysis of the correct reasoning results when the group secured an eight out of twelve gain in correct reasoning with three questions unchanged in correct reasoning and only one showing a loss of reasoning. Clearly with this group the gains outweighed the losses. Furthermore, from the video and the ethnographic notes, it can be observed that learners in this group tended to be more focused and engaged in only minimum discussion. 


\section{Conclusion}

The underlying purpose of the research presented is to identify the amount of guidance required for the effective learning of science concepts when using computer simulation. From the results, it can be concluded that construction of knowledge from discovery learning activities occurs with or without guidance. Indeed, there is no significant difference between the performances of the three groups. The amount of guidance however, had an influence on the amount of conceptual gain achieved and its effect on learner's intuitive knowledge (Kirschner et al., 2006). It can therefore be concluded that the Maximum Guided Group's treatment was the most effective treatment for conceptual change when using computer simulation. In addition, teachers who use computer simulation as a discovery learning tool should always provide enough guidance for effective conceptual change.

It is also important to consider that being computer literate gives the learner a positive computer self-concept which is completely linked to computer interest, engagement and finally learning from the use of computer (Christoph, Goldhammer, Zylka, \& Hartig, 2014). On the other hand it is a challenge for developing and least developed countries like Vanuatu where the majority of students have less exposure, knowledge and skills in the use of computers (Iding \& Singh, 2013; Iding, Skouge, \& Peter, 2008): therefore having a low computer-self-concept will directly influence their motivation and performance.

Finally, the results could be useful for the design of computer simulation activities. Recommendations for future research include the need to test students from different grades and extend the sample of students to provide a more significant analysis. 


\section{References}

Alessi, S. M., \& Trollip, S. R. (1991). Computer-based Instruction: Methods and Development. Englewood Cliffs, NY, US: Prentice Hall.

Alfieri, L., Brooks, P. J., Aldrich, N. J., \& Tenenbaum, H. R. (2011). Does discovery-based instruction enhance learning? Journal of Educational Psychology, 103(1), 1-18. http://doi.org/10.1037/a0021017

Brown, A., \& Campione, J. (1993). Guided discovery in a community of learners. K. McGilly (Ed.), Classroom lessons: Integrating cognitive theory and classroom practice (pp. 229-270).

Chang, K.-E., Chen, Y.-L., Lin, H.-Y., \& Sung, Y.-T. (2008). Effects of learning support in simulation-based physics learning. Computers \& Education, 51(4), 1486-1498.

Christoph, G., Goldhammer, F., Zylka, J., \& Hartig, J. (2014). Adolescents' computer performance: The role of self-concept and motivational aspects. Computers \& Education.

Colaso, V., Kamal, A., Saraiya, P., North, C., McCrickard, S., \& Shaffer, C. (2002). Learning and retention in data structures: A comparison of visualization, text, and combined methods. Presented at the Proc. ED-MEDIA.

Concari, S., Giorgi, S., Cámara, C., \& Giacosa, N. (2006). Didactic strategies using simulations for Physics teaching. Current Developments in Technology-Assisted Education, 3, 2042-2046.

Dawkins, K. R., Dickerson, D. L., McKinney, S. E., \& Butler, S. (2008). Teaching density to middle school students: preservice science teachers' content knowledge and pedagogical practices. The Clearing House: A Journal of Educational Strategies, Issues and Ideas, 82(1), 21-26. 
Derradj, C. (2014). La problematisation dans l'enseignement des sciences physique. Master MEEF Parcours. Unpublished dissertation. University of Aix-Marseille.

Hardiman, P. T., Pollatsek, A., \& Well, A. D. (1986). Learning to understand the balance beam. Cognition and Instruction, 3(1), 63-86.

Helm, H. (1980). Misconceptions in physics amongst South African students. Physics Education, 15(2), 92.

Hewson, M. G. A. (1986). The acquisition of scientific knowledge: Analysis and representation of student conceptions concerning density. Science Education, 70(2), 159-170. http://doi.org/10.1002/sce.3730700210

Hewson, P. W., \& Hewson, M. G. (1984). The role of conceptual conflict in conceptual change and the design of science instruction. Instructional Science, 13(1), 1-13.

Hitt, A. M. (2005). Attacking a dense problem: A learner-centered approach to teaching density. Science Activities: Classroom Projects and Curriculum Ideas, 42(1), 25-29.

Honomichl, R. D., \& Chen, Z. (2012). The role of guidance in children's discovery learning. Wiley Interdisciplinary Reviews: Cognitive Science, 3(6), 615-622. http://doi.org/10.1002/wcs.1199

Iding, M., \& Singh, M. (2013). Improving Computer-Based Education in the Pacific Islands: From Coconut Wireless to Wi-Fi. Retrieved from http://wcce2013.umk.pl/publications/v2/V2.27_103-Iding-FPN.pdf

Iding, M., Skouge, J., \& Peter, J. (2008). The computer and the canoe: web-based communities across the Pacific Islands. International Journal of Web Based Communities, 4(1), 5-16.

ITU. (2013). H.E. Moana Carcasses Katokai Kalosil, PM, Vanuatu - speech at Connect AsiaPacific 2013 Summit - YouTube. Retrieved from https://www.youtube.com/watch?v=hu5euKvam68 
Jong, T. D. (1991). Learning and instruction with computer simulations. Education and Computing, 6(3-4), 217-229. http://doi.org/10.1016/0167-9287(91)80002-F

Jong, T. D., \& Joolingen, W. R. V. (1998). Scientific Discovery Learning with Computer Simulations of Conceptual Domains. Review of Educational Research, 68(2), 179201. http://doi.org/10.3102/00346543068002179

Kirschner, P. A., Sweller, J., \& Clark, R. E. (2006). Why minimal guidance during instruction does not work: An analysis of the failure of constructivist, discovery, problem-based, experiential, and inquiry-based teaching. Educational Psychologist, $41(2), 75-86$.

Lazonder, A. W., Wilhelm, P., \& Hagemans, M. G. (2008). The influence of domain knowledge on strategy use during simulation-based inquiry learning. Learning and Instruction, 18(6), 580-592. http://doi.org/10.1016/j.learninstruc.2007.12.001

Leutner, D. (1993). Guided discovery learning with computer-based simulation games: Effects of adaptive and non-adaptive instructional support. Learning and Instruction, $3(2), 113-132$.

Luo, W., Stravers, J. A., \& Duffin, K. L. (2005). Lessons learned from using a web-based interactive landform simulation model (WILSIM) in a general education physical geography course. Journal of Geoscience Education, 53(5), 489.

Mayer, R. E. (2004). Should there be a three-strikes rule against pure discovery learning? American Psychologist, 59(1), 14.

McKagan, S. B., Perkins, K. K., Dubson, M., Malley, C., Reid, S., LeMaster, R., \& Wieman, C. E. (2008). Developing and researching PhET simulations for teaching quantum mechanics. American Journal of Physics, 76(4), 406-417. http://doi.org/10.1119/1.2885199 
Ministry of Education Republic of Vanuatu. (2013a). Vanuatu National Syllabuses Primary years 1-3. Curriculum Development Unit.

Ministry of Education Republic of Vanuatu. (2013b). Vanuatu National Syllabuses Primary Years 4-6. Curriculum Development Unit.

Miyake, N. (2007). Computer Supported Collaborative Learning. In R. Andrews \& C. Haythornthwaite (Eds.), The SAGE Handbook of E-learning Research (pp. 248-266). UK: SAGE.

Perkins, K., Adams, W., Dubson, M., Finkelstein, N., Reid, S., Wieman, C., \& LeMaster, R. (2006). PhET: Interactive Simulations for Teaching and Learning Physics. The Physics Teacher, 44(1), 18. http://doi.org/10.1119/1.2150754

Piaget, J. (2013). Child's Construction of Quantities: Selected Works (Vol. 8). New York, NY, US: Routledge.

Psycharis, S. (2011). The computational experiment and its effects on approach to learning and beliefs on physics. Computers \& Education, 56(3), 547-555. http://doi.org/10.1016/j.compedu.2010.09.011

Radovanovic, J., \& Slisko, J. (2012). Approximate Value of Buoyant Force: A Water-Filled Balloon Demonstration. The Physics Teacher, 50(7), 428-429. http://doi.org/10.1119/1.4752051

Ren, A. Z., \& Xie, X. Y. (2004). The Simulation of Post-Earthquake Fire-Prone Area Based on GIS. Journal of Fire Sciences, 22(5), 421-439. http://doi.org/10.1177/0734904104042440

Rieber, L. P., Tzeng, S.-C., \& Tribble, K. (2004). Discovery learning, representation, and explanation within a computer-based simulation: finding the right mix. Learning and Instruction, 14(3), 307-323. http://doi.org/10.1016/j.learninstruc.2004.06.008 
Şahin, Ç. (2010). Design, implementation and evaluation of the guided materials based on the 'enriched 5e instructional model' for the elementary 8th grade' force and motion' unit.

Santos, R. P. Dos. (2012). Second Life as a Platform for Physics Simulations and Microworlds: An Evaluation. In Proceedings of the CBLIS 2012-10th Conference on Computer-Based Learning in Science, Barcelona, 26th to (pp. 173-180). Retrieved from http://papers.ssrn.com/sol3/papers.cfm?abstract_id=2441549

Smetana, L. K., \& Bell, R. L. (2012). Computer Simulations to Support Science Instruction and Learning: A critical review of the literature. International Journal of Science Education, 34(9), 1337-1370. http://doi.org/10.1080/09500693.2011.605182

Smitha, V. P. (2012). Inquiry training model and guided discovery learning for fostering critical thinking and scientific attitude (Firts edition). Kozhikode: Vilavath Publication.

Smith, C., Snir, J., \& Grosslight, L. (1992). Using conceptual models to facilitate conceptual change: The case of weight-density differentiation. Cognition and Instruction, 9(3), $221-283$.

Steinberg, R. N. (2000). Computers in teaching science: To simulate or not to simulate? American Journal of Physics, 68(S1), S37-S41. http://doi.org/10.1119/1.19517

Ünal, S., \& Coştu, B. (2005). Problematic issue for students: Does it sink or float. In AsiaPasific Forum on Science Learning and Teaching (Vol. 6, p. 1). Retrieved from http://www.ied.edu.hk/apfsit/download/v6_issue1_files/costu.pdf?origin=publication_ detail

Wieman, C. E., Adams, W. K., Loeblein, P., \& Perkins, K. K. (2010). Teaching Physics Using PhET Simulations. The Physics Teacher, 48(4), 225-227. http://doi.org/10.1119/1.3361987 
Wieman, C. E., Adams, W. K., \& Perkins, K. K. (2008). PhET: Simulations that enhance learning. Science, 322(5902), 682-683.

Wieman, C. E., \& Perkins, K. K. (2006). A powerful tool for teaching science. Nature Physics, 2(5), 290-292.

Xie, Q., \& Tinker, R. (2006). Molecular Dynamics Simulations of Chemical Reactions for Use in Education. Journal of Chemical Education, 83(1), 77. http://doi.org/10.1021/ed083p77

Zhang, M. (2014). Who are interested in online science simulations? Tracking a trend of digital divide in Internet use. Computers \& Education, 76, 205-214.

\section{Appendix A}

Examples of questions take from the questionnaire based on the work of Çepni \& Şahin, (2012):

\section{Questions n.: 3}

Sketch the representation of the three bottles of water when dropped in the water-aquarium
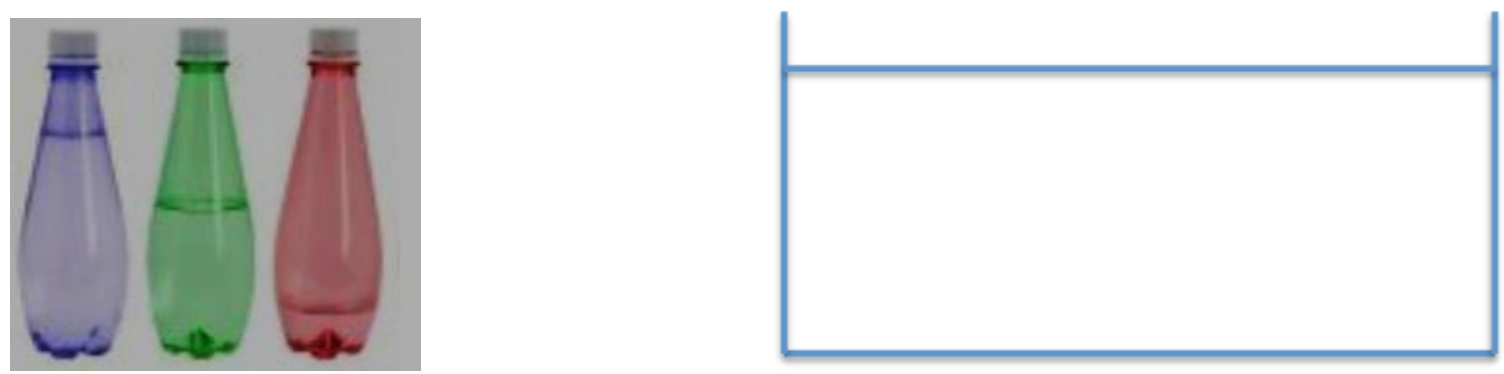
Circle a letter of choice which gives a best explanation for your choice in question 3.1

\begin{tabular}{|l|l|}
\hline Choice & Possible explanation \\
\hline A & Each bottle's position in the water is determined by the amount of water in it. \\
\hline B & Each bottle's position in the water is determined by its weight alone \\
\hline C & Each bottle's position in the water is determined by the amount of air in the bottle \\
\hline D & Each bottle's position in the water is determine by the density of liquid it contains \\
\hline
\end{tabular}

\section{Question n. 10}

This aquarium is filled with oil. Sketch the representation of these wooden and metal balls when dropped into it.
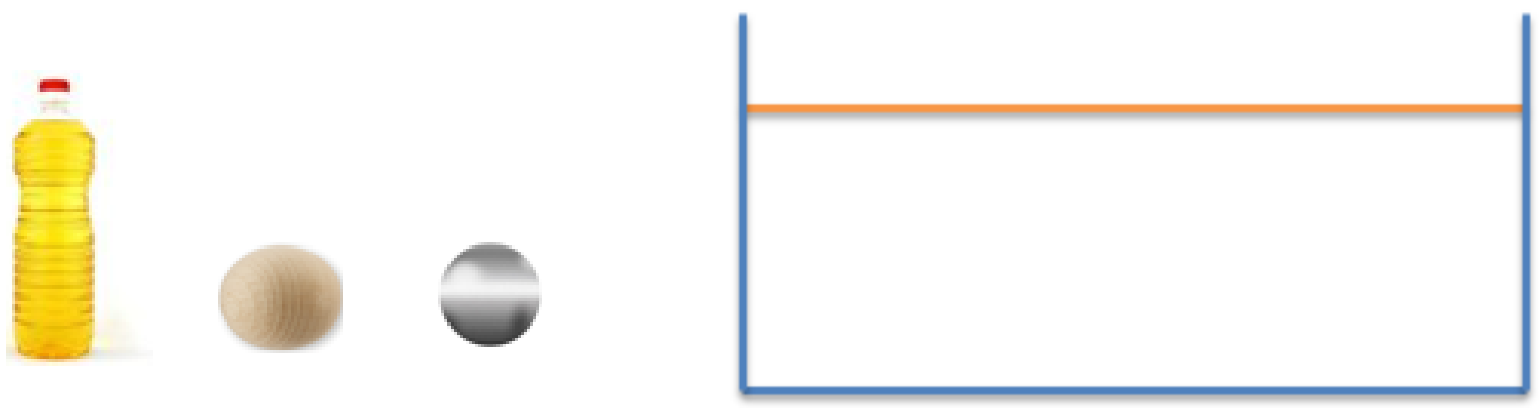

Circle a letter of choice which gives a best explanation for your choice in question

\begin{tabular}{|l|l|}
\hline Choice & Possible explanation \\
\hline A & Each ball's position in the oil is similar to that of water \\
\hline B & Some part of both ball's will be emerged on the surface of the oil \\
\hline C & Both ball's will be at the bottom of the aquarium \\
\hline D & $\begin{array}{l}\text { A larger part or larger fraction of the wooden ball will be emerged and the metal } \\
\text { ball will maintain its position compared to that if it was in water }\end{array}$ \\
\hline E & Both ball's hang in the oil with the wooden ball above the metal ball \\
\hline
\end{tabular}

\section{Question n. 12}

In the pictures below, substances with the same volume are placed into the barrels filled with water. Which one of these substances will cause equal amounts of water from the barrels to over flow? 
I)

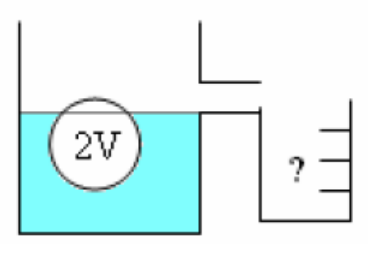

II)

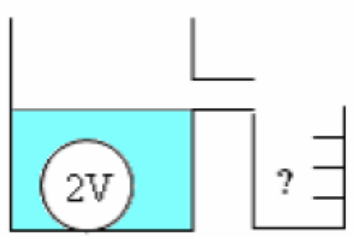

III)

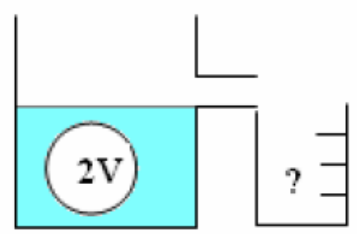

IV)

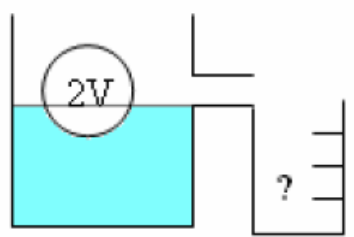
A.II and IV
B.II and III
C.III and IV
D.I and IV

Circle a letter of choice which gives a best explanation for your choice in question 11.1

\begin{tabular}{|l|l|}
\hline Choice & Possible explanation \\
\hline A & Because the mass of both objects are equal \\
\hline B & Because both of those two objects are heavier than water \\
\hline C & Because the amount of overflowing water of the submerged object is equal \\
\hline D & Because the displaced water is equal to the submerged volume of water \\
\hline E & Because both objects are under the water \\
\hline F & Because parts of both objects are above the water \\
\hline
\end{tabular}

Appendix B

Task from the activity on density proposed in the training sessions (Retrieved online from http://phet.colorado.edu/sims/density-and-buoyancy/density_en.html the 17/12/2014):

\begin{tabular}{|l|l|l|l|l|}
\hline Material & Mass (kg) & Volume (L) & Density (kg/L) & Does it Float? \\
\hline Styrofoam & & & & \\
\hline Wood & & & & \\
\hline Ice & & & & \\
\hline Brick & & & & \\
\hline Aluminum & & & & \\
\hline
\end{tabular}

In the custom setting, choose the 'My block' option in the material drop down box. Set the mass of your object to $4 \mathrm{~kg}$. Adjust the volume to find the minimum volume needed to make the object float. 
Volume

Density

How does the density of a large piece of aluminium compare to a small piece? 